\title{
Rule 34(c) and Discovery of Nonparty Land
}

The discovery system of the Federal Rules of Civil Procedure contains a curious gap. Rule $34(\mathrm{a})(1)$ provides discovery of parties' documents and tangible things; ${ }^{1}$ Rule 34(a)(2), of parties' land;'² and Rule 45(d), of nonparties' documents and tangible things. ${ }^{3}$ However, no rule provides discovery of nonparties' land. ${ }^{4}$ The 1970 amendments to the Rules addressed this limitation by adding Rule 34(c), which reads: "This rule [34] does not preclude an independent action against a person not a party for production of documents and things and permission to enter upon land." This provision has given rise to confusion and uncertainty among practitioners ${ }^{5}$ but as yet to no reported decisions; ${ }^{6}$ commentators treat it cursorily. ${ }^{7}$

\section{FED. R. CIv. P. 34(a) provides:}

Any party may serve on any other party a request (1) to produce and permit the party making the request, or someone acting on his behalf, to inspect and copy, any designated documents ... . or to inspect and copy, test, or sample any tangible things which constitute or contain matters within the scope of Rule 26(b) and which are in the possession, custody or control of the party upon whom the request is served ....

2. FED. R. Crv. P. 34(a) continues:

$[\mathrm{O}] \mathrm{r}(2)$ to permit entry upon designated land or other property in the passession or control of the party upon whom the request is served for the purpose of inspection and measuring, surveying, photographing, testing, or sampling the property or any designated object or operation thereon, within the scope of Rule 26(b).

The phrase "other property" refers to structures and large objects, such as a ship or a machine, which cannot be brought into a deposition room. 4A J. Moore, FEderal. Prictice If 34.18 at $34-102$ (2d ed. 1975) [hereinafter cited as Moore]; see Notes of Advisory Committee on 1970 Amendment to Rules, FED. R. Civ. P. 34, 28 U.S.C. app., at 7794 (1970) (Rule 34(a) now provides testing and sampling of "objects or operations on land"; Rule 34(c) motivated by occasional need for inspection of "large tangible things" as well as land). This Note refers only to "land," although the analysis applies as well to "other property" within the scope of Rule 34(a)(2).

3. FED. R. Civ. P. 45(d)(1) provides:

The subpoena [for taking a deposition] may command the person to whom it is directed to produce and permit inspection and copying of designated books, papers, documents, or tangible things which constitute or contain matters within the scope of the examination permitted by Rule $26(\mathrm{~b})$. . . .

4. The language of Rule 34(a) clearly restricts it to parties. See note I supra and 4.1 Moore, supra note 2, I 34.05[1]; 8 C. Wricht \& A. Miller, Federal Practice and ProCedure $\S 2209$ (1970) [hereinafter cited as Wricht \& Miller]; 2A W. Barron \& A. Holtzoff, Federal Practice and Procenure $\$ 791$ (C. Wright ed. 1961). Unlike the Federal Rules, a number of state procedural codes expressly permit inspection of the land of any person. See 8 WRIGHT \& MILLER, supra at 619-20.

5. See New Federal Civil Discovery Rules Sourcebook 126-30 (PLI Litigation Sourcebook Ser. No. 4, W. Treadwell ed. 1972) [hereinafter cited as Discoverr Sourcebook].

6. But cf. United States v. 25.02 Acres of Land, 495 F.2d 1398, 1402 (10th Cir. 1974) (upholding district court's discretion to quash subpoena duces tecum for production of reports from appraisals made for private landowners not parties to condemnation case; passing reference to Rule $34(c)$ ).

7. See, e.g., 4A MoOre, supra note 2, If 34.22; 8 WRIGHT \& MiLLER, supra note 4, \$ 
This Note examines Rule 34(c) and the independent actions to which it might refer. The Note argues that such actions are ineffective in obtaining inspection of nonparty land and, even if expanded to become effective, are inconsistent with the policies underlying the discovery system of the Federal Rules. The Note then proposes further action by the draftsmen of the Federal Rules to shape a discovery tool for nonparty land within the framework of the Rules.

\section{Background and Purpose of Rule 34(c)}

The need to obtain discovery of nonparty land may arise in a variety of situations: to inspect an allegedly defective machine in a suit against its manufacturer by a worker injured at his job and barred by a workmen's compensation statute from joining his employer as a defendant; ${ }^{8}$ to inspect the site of a plane crash in a mass tort action; to obtain an appraisal of neighboring land in a condemnation proceeding; 9 to test the soil or water of land adjacent to the plaintiff's in an action against an alleged polluter; ${ }^{10}$ or to inspect land which was owned by a party at the time the cause of action arose but has since been transferred. This need was brought to the attention of the Advisory Committee in drafting the 1970 amendments to Rule 34 . In its note accompanying the 1967 preliminary draft, which did not include the present subdivision (c), the Committee explained that a suggestion had been made to authorize a court to order nonparties to permit entry on land. ${ }^{11}$ Observing that neither the reported cases nor the commentators had shown the need for this provision, the Committee

2209; Kalmus, Discovery of Documents and Things, in DIscoverY Sourcerook, supra note 5 , at $119,125-26$.

8. 8 Wricht \& Miller, supra note 4 , $\$ 2209$, at 619 . See also 4 A Moore, supra note 2, If 34.22; Backlund v. General Motors Corp., 352 Mass. 776, 226 N.E.2d 555 (1967) (rescript opinion). Cf. Humphries v. Pennsylvania R.R., 14 F.R.D. 177, 181 (N.D. Ohio 1953) (action by an employee of a steel plant against a railroad company for personal injuries sustained through the negligence of the railroad which operated its freight cars on the premises of the steel plant; inspection of the site of the accident denied because steel company, which owned and controlled the premises, was not a party).

9. Cf. United States v. 25.02 Acres of Land, 495 F.2d 1398, 1402 (10th Cir. 19'74) (discovery of appraisal reports for neighboring land sought in condemnation procecding). One method of valuation in condemnation procecdings is to tuse the price at which comparable property has recently been sold. See 7 Nichols' THE LAw of EMINENT Domain If 4.08[1] (rev. 3d ed. P. Rohan \& M. Reskin 1975). Inspection of nonparty land may be nccessary to establish the "comparability" of land used for the valuation.

10. Cf. Martin v. Reynolds Mletal Corp., 297 F.2d 49 (9th Cir. 1961) (in suit by Iandowners for damage to cattle caused by aluminum plant's effluents, prospective defendant allowed to test soil and vegetation on affected land).

11. Judicial Conference of the United States, Committec on Rules of Practice and Procedure, Preliminary Draft of Proposed Amendments to Rules of Civil Procedure for the United States District Courts relating to Deposition and Discovery, 43 F.R.D. 211, 255-57 (1967). 
invited reports of difficulties from the bar. ${ }^{12}$ By the time the final version of the proposed amendments was prepared, such reports ${ }^{13}$ had convinced the Committee that it was occasionally necessary to inspect land in the possession of a nonparty. ${ }^{14}$

Rather than provide directly for discovery against nonparties by a provision in the Rules, ${ }^{15}$ the Advisory Committee chose to solve a more limited problem. Some courts had dismissed independent discovery actions for inspection of nonparty land on the ground that Rule 34(a), which provides inspection of a party's land, was preemptive. ${ }^{16}$ The Committee added Rule $34(\mathrm{c})$, which simply makes clear that such independent actions are not precluded. ${ }^{17}$ Since the Rule contains no language which authorizes discovery of nonparty land, ${ }^{18}$ the availability of such discovery depends entirely on whatever independent action might be brought.

\section{Independent Actions}

The drafters of Rule 34(c) apparently contemplated that the courts would revive the former bill in equity for discovery. ${ }^{19}$ Before discovery practice was codified, ${ }^{20}$ the bill was the primary means for obtaining discovery both at law and in equity; ${ }^{21}$ it was used to extend the limited

12. Id. at 257 .

13. There were "something like half a dozen" reports. Discovery Sourcedook, supra note 5, at 128 (remarks by Prof. [now Dean] Albert Sacks).

14. Notes of Advisory Conmittee on 1970 Amendment to Rules, Fed. R. Cw. P. 34(c), 28 U.S.C. app., at 7794 (1970) [hereinafter cited as Advisory Committee Note].

15. See pp. 120-2I infra.

16. Advisory Committee Note, supra note 14; cf. Amand v. Pennsylvania R.R., 17 F.R.D. 290 (D.N.J. 1955) (independent action for discovery in aid of proceeding before a labor arbitration board dismissed becausc Federal Rules of Civil Procedure preempt any previously existing discovery devices).

17. Advisory Committee Note, supra note 14.

18. According to its Reporter, the Committee intended that no such authorization be implied and that the shaping of a discovery device, if one were to exist at all, be left to the courts. Telephone interview with Dean Albert Sacks, Harvard Law School, May 30, 1975 (notes on file with Yale Law Journal).

19. The Advisory Committee Note, supra note 14 , stated that "some courts harc dismissed independent actions in the nature of bills in equity for such disco'ery" and then added that Rule 34 does not preclude "independent actions" against nonparties (emphasis added).

20. Codification of discovery practice began in the states and in England in the mid-19th century. While the bill remained alive in some jurisdictions, it was more frequently preempted if not abolished outright by such codifications. See generally G. RAGLAND, Discovery Before TRIAL (1932).

21. Historically, the bill in equity for discovery evolved in response to the common law constraint which prevented parties from testifying. This constraint prevented the plaintiff from proving his case when vital information was known only to the defendant. In courts of equity, however, the defendant was obliged to respond under oath to his opponent's factual allegations. It became customary to attach interrogatories to bills in equity, and discovery became incidental to equitable proceedings. These interrogatories grew into an independent equitable remedy, the "pure" bill of discovery, which could 
discovery available in federal practice ${ }^{22}$ until 1938, when the discovery provisions of the Federal Rules of Civil Procedure rendered it largely obsolete..$^{23}$

In its historical form the bill is not capable of filling the gap to which Rule $34(\mathrm{c})$ is addressed. Although the bill traditionally afforded inspection of land, ${ }^{2+}$ it ran only against parties. ${ }^{25}$ There were certain limited exceptions to this rule; the bill would lie against real parties in interest and parties' representatives and agents, ${ }^{20}$ and against any

also be brought in aid of an action at law. See Millar, The Mechanism of Fact Discovery, 32 IL.. L. REv. 261, 424, 437.52 (1937); Developments in the Law-Discovery, 74 HARv. L. Rev. 940, 946-50 (1961). See generally E. Briy, The Principles and Practice of Discovery (1885); T. Hare, Treatise on Discovery of Evidence BY Bill and ANSWer IN EQuity (2d Am. ed. 1849); C. Langdel. A Summary of Equity Pleading \$\$ 167-81 (2d ed. 1883); 1 J. Pomeroy, A Treatise on Equity Jurisprudexce $\$ \$$ 190-207 (5th ed. 1941); 2 J. Story, Commentiries on Equity JuRisprudence $\$ \$$ 1928-56 (14th ed. 1918); 6 J. Wigmore, EVidence $\$ \$ 1845-47$ (3d ed. 1940); J. Wigram, Points IN the LAw of Discovery (lst Am. ed. 1841 ).

22. For a discussion of the limitations on discovery in federal practice before the Rules, see 4 Moore, supra note 2, If 26.03; 4 A Moore 19 T 33.03, 34.03; Pike \& Willis, The New Federal Deposition-Discovery Procedure, 38 Colum. L. Rev. 1179, 1181-84 (1938).

The bill was used principally in aid of actions at law. See, e.g., Pressed Steel Car Co. v. Union Pac. R.R., 240 F. 135 (S.D.N.Y. 1917) (bill in aid of law action afforded inspection of documents where production at trial under subpoena duces tecum would have been impractical). In suits in equity, former Equity Rule 58 permitted a party to submit to his opponent interrogatories, requests for the production of documents, and requests for admission of the genuineness of documents. Rules of Practice for the Courts of Equity of the United States, 198 F. v, xxxiv (1912). But the equity bill could be used to obtain discovery in situations not covered by the Equity Rule. See, e.g., Arms \& Drury, Inc. v. Burg, 90 F.2d 400 (D.C. Cir. 1937) (suit in equity to void deeds; discovery obtained from sales agent to identify purchasers of deeds).

23. 4 MOORE, supra note 2, I 26.53. The Rules do not permit discovery in advance of an action for the purpose of obtaining facts on which to base a complaint. Id. \27.07[4]. Hence the bill may still be useful to enable a plaintiff to find out whom he should sue. Id. I 26.53; see note 27 infra.

24. The bill was originally used to obtain admissions, and was later extended to afford production of documents and tangible things and inspection of land. See, e.g., Thornburgh v. Savage Mining Co., 23 F. Cas. 1113 (No. 13,986) (C.C.D. Nev. 1867) (inspection of land in action for underground trespass); $1 \mathrm{~J}$. POMERoY, supra note $21, \$$ $207 \mathrm{~b} ; 6 \mathrm{~J}$. WigMone, supra note $21, \$ 1862$.

25. See Dehne v. Hillman Inv. Co., $110 \mathrm{~F} .2 \mathrm{~d} 456,458$ (3d Cir. 1940) ("At common law a bill of discovery was demurrable if it lay against a defendant who was a mere witness."); $6 \mathrm{~J}$. WIGMORE, stupra note 21 , $\$ 1856 d$, at 439 ("The principle of a bill of discovery was never considered to be applicable to third persons not parties so as to secure from them before trial a disclosure of possible evidence . . . "); T. HARE, supra note 21, at 67 (discovery confined to party of record). For an explanation of the origins of this restriction, see note 21 supra. The only jurisdiction which has rejected the limitation of the bill to parties appears to be New Hampshire. See Therrien v. Public Serv. Co., 99 N.H. 197, 108 A.2d 48 (1954); Lefebvre v. Somersworth Shoe Co., 93 N.H. 354, 41 A.2d 924 (1915).

26. Sce, e.g.; Finance Co. of America v. Brock, 80 F.2d 713 (5th Cir. 1936) (discovery allowed from corporate officers in action against corporation); Hucy v. Brown, 171 F. 641 (3d Cir. 1909) (broker holding stock as agent compelled to reveal identity of owner in action by corporation's receiver to collect assessment against stockholders); American Sec. \& Trust Co. v. Brooks, 225 Mass. 500, 502, 114 N.E. 732 (1917) (discovery not available from mere witness, but only from parties, members and officers of corporation, parties' agents, or persons against whom relief could be obtained in the main action); 
person not a party to compel disclosure of the identity of the proper defendant. $^{27}$ As a general matter, however, the bill could not provide discovery of nonparty land.28

Although the equity bill in its historical form fails to provide the needed discovery, it has been broadened in scope from time to time by judicial action ${ }^{29}$ and might be expanded to provide discovery from a nonparty. But an equity bill running against nonparties poses a serious jurisdictional problem. The traditional bill for discovery was considered ancillary to the main action; ${ }^{30}$ hence it did not have to

Macclesfield v. Davis, 35 Eng. Rep. 385 (Ch. 1814) (discovery from defendant's banker who was considered owner's agent and had custody of chattels sought to be inspected); E. BRAY, supra note 21 , at $39-40$ (discovery only from parties and persons in community of interest with them); I J. PoMeroy, supra note 21, $\$ 199$ (a) (bill would lic against real party in interest).

27. See, e.g., Arms \& Drury, Inc. v. Burg, 90 F.2d 400 (D.C. Cir. 1937) (in action to void deeds, discovery from sales agent to identify purchasers of deeds); Huey $v$. Brown, 171 F. 641 (3d Cir. 1909) (in action by corporation's receiver to collect assessments against stockholders, broker holding stock as agent compelled to reveal owner's identity); CocaCola Co. v. Atlanta, 152 Ga. 558, 110 S.E. 730 (1922); Bluefield Supply Co. 1. Broome, 121 W. Va. 584, 5 S.E.2d 530 (1939) (labor union forced to reveal identity of members who had made unauthorized contract with petitioner); Orr v. Diaper, 4 Ch. D. (92) (I876) (shipper forced to reveal identity of manufacturer of goods bearing counterfeit trademarks); Heathecote v. Fleete, 23 Eng. Rep. 883 (Ch. 1702) (bill to discover identity of owner of a barge whose operator had negligently damaged the goods of the pros. pective plaintiff); Note, Equily's Bill for Discovery: A Unique Application in the Ficlt of Products Liability, 49 CHI.-KENT L. REv. 124 (1972) (proposal to use discovery bill in advance of action in order to increase the information available to prospective plaintiffs in state and federal actions).

28. There are two cases which might be cited in support of a bill to obtain stich discovery. In an early federal case, a circuit court issued the broad dictum that bills for discovery are not confined to parties but can be brought against any person interested in the action at law who has possession of the evidence sought. Under the facts of the case, however, the respondent to the bill was the real party in interest in the main action. Griesa v. Mutual Life Ins. Co., 169 F. 509, 514 (9th Cir.), cert. denicd, 215 U.S. 600 (1909) (disinterment of body ordered in action by insurance company to void policy because of decedent insured's alleged suicide; defendant was decedent's administrator and owner of burial plot was decedent's widow, the chicf beneficiary of the insurance policy and hence the real party in interest).

More recently a state court granted a plaintiff entry on a nonparty's land to inspect defendant's property to which defendant had a right of access. At the same time, however, the court approved the rule that bills of discovery do not run against nonparties, and found the case at bar distinguishable. Maclherson v. Boston Edison Co., 336 Mass. 94,142 N.E.2d 758 (1957).

29. See Sinclair Ref. Co. v, Jenkins Petroleum Process Co., 289 U.S. 689, 693 (193:3) (Cardozo, J.) ("[w] hen this necessity [for discovery] is made out with reasonable ccltainty, a bill in equity is maintainable to give [the litigant] what he needs"; discovery of damages in patent infringement suit allowed before liability determined); Brown v. McDonald, 133 F. 897 (3d Cir. 1905) (first case in which federal court gave discovery to identify unknown defendant); Shimadzu v. Electric Storage Battery Co., 6 F. Supp. 393 (E.D. Pa. 1934) (entry upon premises to observe defendant's production process where prima facie case of patent infringement established and direct observation only feasible method of proving disputed facts); Levin v. Cleveland Welding Co., 187 N.E.2d 187 (Ohio Ct. App. 1963) (equitable discovery extended to chattels where in that jurisdiction it had traditionally reached only documents).

30. Loft, Inc. v. Corn Prod. Ref. Co., 103 F.2d 1, 9-10 (7th Cir.), cert. denied, 308 
satisfy separate federal jurisdictional or venue provisions. ${ }^{31}$ Presumably ancillary jurisdiction would also exist for a discovery bill running against a nonparty. ${ }^{32}$ However, the problem of personal jurisdiction is not so easily solved. When an ancillary action is brought against a nonparty, personal service must be effected. ${ }^{33}$ For this reason, the bill would often fail when the landowner resides outside the state where the main action is brought. ${ }^{34}$

In addition to its failure to run against nonparties, a number of other traditional limitations ${ }^{35}$ on the use of the bill would have to be overcome. Equitable discovery was generally limited to information relevant to a party's own claims and defenses..$^{30}$ Furthermore, it was available only to the plaintiff, so that a defendant seeking discovery had to file a cross complaint in order to obtain discovery. ${ }^{37}$

U.S. 558 (1939); Baush Mach. Tool Co. v. Aluminum Co. of America, 63 F.2d 778, 779-80 (2d Cir.), cert. denied, 289 U.S. 739 (1933); Zolla v. Grand Rapids Store Equip. Corp., 46 F.2d 319 (S.D.N.Y. 1931).

31. I Moore, supra note 2, If 0.90[3], at 828, 0.140[8], at 1334-35; 2A Moore II 8.07[5]; 13 WRIGHT \& Miller, supra note $4, \S 3523$, at 56 \& cases cited in nn.1-2.

32. That ancillary jurisdiction may exist over a proceeding against a person not a party to the main action is shown by FED. R. Giv. P. 27(a), which provides that a person may file a verified petition in federal court seeking to perpetuate his own testimony "or that of another person." The petition to perpetuate testimony, which may run against nonparty witnesses, is cognizable in the federal courts under the principle of ancillary jurisdiction. 4 MOORE, supra note 2, if 27.03. The Rule 27(a) petition is based on the equitable bill to perpetuate testimony, which also ran against nonparties. In a comment appended to a draft of Rule 27, the Advisory Committee interpreted Union Solvents Corp. v. Butacet Corp., 2 F. Supp. 375 (D. Del. 1993), to hold that an equitable bill to perpetuate testimony was not ancillary but instead required its own federal jurisdictional grounds. 4 MOORE, supra note 2, $\mathbb{2} 27.03$, at 181 n.4. The Advisory Committee's view of Union Solvents scems wrong. The Committee did not explain its interpretation, and while some commentators have accepted it uncritically, 8 Wrighr \& MILLER, supra note 4, $\$ 2072$, at 335 n.14, Professor Moore has persuasively argued against it. 4 Moore, supra. Morcover, if the Committee were correct that the bill to perpetuate testimony required independent grounds of federal jurisdiction, then the provision in Rule 27 (a) for an ancillary petition to perpetuate testimony expands the jurisdiction of the district courts against the command of Rule 82 , which provides that the Rules may not "extend or limit the jurisdiction of the United States district courts . . . Assuming that Rule 27(a) is valid, the equitable bill to perpetuate testimony must also have been ancillary.

33. 2 Moore, supra note 2, If 4.13, at 1060-61; 13 Wricht \& Mrller, supra note 4, $\$ 3523$, at 72 .

34. See FED. R. Civ. P. 4(f). Personal jurisdiction over a nonresident could be obtained by use of a state long-arm statute. 2 MOORE, supra note $2, \pi 4.42[1]$, [2].

If the problem of personal service were circumvented by filing the bill in the district court in the state of residence of the respondent from whom discovery were sought, then the court would lack the ancillary jurisdiction needed to entertain discovery bills in the federal courts. See cases cited in note 30 supra (bills allowed on ground that main action pending in same jurisdiction).

35. For a survey of the restrictions on use of the bill, including others not mentioned in the text, see $1 \mathrm{~J}$. POMERoY, supra note $21, \$ \$ 201-07,207 \mathrm{~b}$.

36. There is, however, a split of authority concerning this limitation. 4 Moore, supra note 2, 9 26.03[1]; P. DYer-SMith, Federal Examinations before Trial and Depositions PRACTICE $\$ \$ 17$ n.12, 248 (1939).

37. $1 \mathrm{~J}$. POMEROY, supra note 21 , $\$ 198$, at 301 . 
Finally, the granting of the bill was discretionary. ${ }^{38}$ Although none of these problems is insurmountable, the process of adapting the archaic equity bill to provide a modern discovery tool for nonparty land would entail considerable litigation, with attendant cost, uncertainty, and inconsistency. ${ }^{39}$

Although the most significant, the equity bill is not the only independent action which might be brought for discovery of nonparty land. It is conceivable that the action to perpetuate testimony, expressly preserved by Rule 27(c), could serve as the basis for the judicial creation of the independent action to which Rule 34(c) refers. ${ }^{40}$ Although this action can be brought against a nonparty witness, it is available only to obtain evidence known to exist and hence would be even more difficult to transform into a discovery device for nonparty land than the discovery bill. ${ }^{41}$ Another possible independent action would be a petition for one of the extraordinary writs under the All Writs Statute. ${ }^{42}$ This statute can be used by the district courts to afford discovery in actions not covered by the Rules, such as habeas corpus proceedings, ${ }^{43}$ but cannot be used in actions to which the Rules ap-

38. Sinclair Ref. Co. v. Jenkins Petroleum Process Co., 289 U.S. 689, 696-97 (1933). The bill may even have been subject to denial without a statement of reasons. See Top Value Enterprises, Inc. v. Borrelli, 350 Mass. 722, 216 N.E.2d 874 (1966).

39. For example, although the independent discovery action would be governed by the Federal Rules, 4 Moore, supra note 2, đ 26.53, at 26-104, practitioners have expressed concern that the party bringing the discovery action might fail to give notice to the other parties as required by the Rules. See Discovery Sourcebook, supra note 5, at 126-30.

40. For an exposition of the origins of this action in the ancient equity bills to take depositions de bene esse and under dedimus potestatem, see $1 \mathrm{~J}$. PoMeroy, supra note 21, $\$$ 210-11, 213-14; 2 T. Street, Federal Equity Practice $\$ \$ 1765-91$ (1909). In a few jurisdictions the old equity bills for the preservation of testimony have provided the historical foundations for the creation of modern discovery devices. See G. RigLAND, supra note 20 , at 20-21, 50 .

41. See J. Pomeroy, supra note 21, $\$ \$ 210-11 ; 2$ T. STREeT, supra note $40, \$ \$ 1765-91$ (limitations on the scope and purpose of the bills to perpetuate testimony; narrowly defined prerequisites for invoking the bills); see also 4 MOORE, supra note 2, $\$ 26.03$ [1] (limitations under federal statutes codifying bills).

42. The All Writs Statute, 28 U.S.C. $\$ 1651$ (1970), provides that "courts . . . may issue all writs necessary or appropriate in aid of their respective jurisdictions and agrecable to the usages and principles of law." See Blair, A Guide to the New Federal Discovery Practice, 21 Drake L. Rev. 58, 72 n.62 (1971).

43. See Harris v. Nelson, 394 U.S. 286, 298-300 (1969) (FED. R. Civ. P. not applicable to habeas corpus proceedings, but $\S 1651$ authorizes courts to fashion appropriate discovery procedure; statute is a "legislatively approved source of procedural instruments designed to achieve the "rational ends of law" "). The proposed federal habeas corpus rules likewise refer the question of discovery to the discretion of the comrt. See Habcas Corpus Rule 6, $\$ 2255$, Comm. ON Rules of Practice and Procedure of the Judicial Conf. of the United States, Proposed Amendilents to the Fed. Rules of Criminal Procedure, Proposed Rules Governing Habeas Corpus Proceedings, Proposed Rules Governing § 2255 Proceedings for the United States District Courts ANd Proposed Amendment to the Fed. Rules of Appelilate Procedure 62-64, 113-14 (prelim. draft, Jan. 1973). Tribunals to which the Federal Rules do not apply may also use $\$ 1651$ 
ply.44 Moreover, a court may not issue the writ to a person over whom it has not already acquired jurisdiction; ${ }^{45}$ hence the writ would generally not be available for discovery from nonparties.

The fundamental objection to an independent discovery action, regardless of the form it may take, is that it is contrary to the policies represented by the discovery provisions of the Federal Rules. The purpose of these provisions was to replace the unrelated and haphazard devices which had developed by a process of historical accretion with an integrated and efficient system of pretrial investigation; $;^{46}$ simpler procedures were substituted for the cumbersome bill in equity of the former practice. ${ }^{47}$ This purpose was reaffirmed by the 1970 amendments to the Rules, which further reduced judicial involvement ${ }^{48}$ and eliminated it altogether from Rule $34(a) .{ }^{49}$ It was surely inconsistent to provide extrajudicial discovery of parties' land in one section of Rule 34 and at the same time to resurrect independent actions for discovery of nonparties' land in another section. ${ }^{50}$

to create their own discovery tools. See Olson Rug Co. v. NLRB, 291 F.2d 655 (7th Cir. 1961) (in proceeding upon petition by NLRB to hold employer in civil contempt, special master appointed by court of appeals could order discovery of Board's doctiments); Bethlehem Shipbldg. Corp. v. NLRB, 120 F.2d 126, 127 (1st Cir. 1941) (per curiam) (discovery order by court of appeals in action challenging NLRB decision); Kamen Soap Prod. Co. v. United States, 110 F. Supp. 430, 438 (Ct. CI. 1953) (subpoena available even though not expressly authorized by Court of Claims discovery rules).

44. Neuwirth v. Merin, 267 F. Supp. 333 (S.D.N.Y. 1967) (since list of stockholders in derivative action not discoverable under the FED. R. Civ. P., court has no basis for mandamus compelling production).

45. Commercial Sec. Bank v. Walker Bank \& Trust Co., 456 F.2d 1352, 1355 (10th Cir. 1972) ("court may not [by an order under $\$ 1651$ ] acquire jurisdiction over an individual or property not otherwise subject to its jurisdiction"); Morrow v. District of Columbia, 417 F.2d 728, 733 (D.C. Cir. 1969) (dictum); 9 MOoRE, supra note 2, II 110.29, at 318.

46. See Pike \& Willis, supra note 22, at 1186; 8 WRIGHT \& Miller, supra note 4, $\$ 2002$, at 21 (FED. R. Crv. P. 26 through 37 intended to take the best of English and state practices and make them available in federal courts, where previous discovery mechanisms had been cumbersome and restricted).

47. See 4 MoORE, supra note $2, \uparrow 26.03[1]$, at 26-82.

48. Advisory Committee's Explanatory Statement Concerning 1970 Amendments of the Discovery Rules, 28 U.S.C. app., at 7772 (1970).

49. The amendment eliminated the requirement of a court order issued upon a showing of good cause. $4 \mathrm{~A}$ MOorE, supra note 2, If 34.01[7], [8].

50. The existence of Rule 27(c), which permits independent actions for the perpetuation of testimony, might be taken as an endorsement of the place of independent actions within the framework of the Rules. But the Rule 27 (c) independent action is not the basic discovery device for preservation of testimony; it supplements a less cumbersome proceeding under Rule $27(\mathrm{a})$ by occasionally providing a more convenient venue for depositions to preserve testimony than that provided by Rule 27(a). See 4 Moore, supra note 2, If 27.02, 27.21. An independent action under Rule 34(c), howcver, would not supplement an existing provision for discovery of nonparty land. Moreover, even under Rule 27(a) preservation of testimony does not operate extrajudicially, and hence the use of an independent action to perpetuate testimony represents a minimal departure from the standard procedure provided by the Rules. 
Finding no suitable independent action under Rule 34(c), a court might be tempted to grant a motion for an order compelling a nonparty to permit entry on his land.51 Such a judicial amendment to the Rules would be improper; the courts "have no power to rewrite the Rules by judicial interpretations." 52

\section{Amending Rule 45(d) to Provide Discovery of Nonparty Land}

The Advisory Committee seems to have been aware of the limitations on the use of the independent actions for discovery of nonparty land. The Committee stated that "an ideal solution to this problem is to provide for discovery against persons not parties in Rule 34," but decided not to adopt this solution because "both the jurisdictional and procedural problems are very complex." 53

Any procedural and jurisdictional problems involved in extending the Rules to cover inspection of nonparty land would apply equally to the inspection of a nonparty's documents or tangible things under Rule $45(\mathrm{~d}) .^{54}$ Rule $45(\mathrm{~d})$ has provided for discovery of a nonparty's

51. The court would have to assume that the drafters intended to make a nonparty's land discoverable and that they could not have intended to preserve an illusory remedy in Rule 34(c). Under such an assumption the court might ignore the language of $34(\mathrm{c})$ calling for an "independent action" and interpret the Rule to authorize entry on nonparty land by court order. Cf. In ve Fitzgerald, I6 FED. Rules SERv. 2D 1052, 1053 (D.D.C. 1972), criticized, 4 Moore; supra note 2, 927.21 n.8 (Supp. 1974) (court ordered deposition to preserve testimony for an administrative proceeding-a deposition not anthorized by Federal Rules-on ground that Rule 27 (c), authorizing independent actions to perpetuate testimony, would be "superfluous" if not construed to give "flexibility" in permitting depositions to be taken).

52. Harris v. Nelson, 394 U.S. 286, 298 (1969) (applying "conventional principles of statutory construction" to Rule $81(a)(2)$, Court held that discovery provisions of Federal Rules do not extend to habeas corpus proceedings).

53. Advisory Committee Note, supra note 14 .

54. For the relevant text of Rule 45 (d), see note 3 supra.

It might be argued that inspection of land located outside the district where the subpoena is served on the nonparty presents a problem not posed by inspection of documents and tangible things: land, unlike documents, cannot be moved and therefore must be inspected outside the nonparty's district. Since the subpoena generally reaches documents under the control of the person ordered to produce, even if the materials are outside the district where the person is served, 5.t MOORE, supra note 2, ff 45.05[1], at 45-32, the enlarged subpoena should reach land similarly located and controlled. $A$ s a practical matter, the inconvenience of transporting large numbers of documents will often make it necessary to inspect them where they are kept by the nonparty. See Hogan v. Ultronic Sys. Corp., 8 Fed. Rules Serv. 20 45b.31, Case I (S.D.N.Y. 1964) (deposition ordered at office of witness in order to avoid inconvenience of moving numcrous documents to be inspected); $5 \mathrm{~A}$ MoORE, supra I 45.07[2], at 45-74 n.31 (court could order nonparty to produce documents in a district more convenient than where subpoena scrved); sce also Less v. Taber Instrument Corp., 53 F.R.D. 645 (W.D.N.Y. 1971) (court ordered that deposition of corporation served with a subpoena in New York should be taken in California). Hence inspection of land outside the district where the subpoena is served should not create difficulties which have not already been faced in document inspection. 
documents since the adoption of the Rules in 1938 and for discovery of a nonparty's tangible things since 1946.55 The Rule has proved a useful discovery device which has not given rise to complex jurisdictional and procedural problems. The Advisory Committee saw no such problems in the extension of the Rule 45 (d) subpoena to a nonparty's tangible things in $1946 ; 56$ the extension has not provoked any challenges in reported cases and has not been questioned by commentators. .57

It is quite possible that the Committee was referring to the technical problems of meshing a revised Rule 34 with other Rules. ${ }^{58}$ The drafting problems stem from the need to provide a mechanism for discovery against nonparties in a Rule which now applies only to parties. The easiest way to provide this mechanism would be to amend Rule 45 (d) to authorize a subpoena compelling a person to permit inspection of his land. ${ }^{59}$ Discovery of nonparty land would then fol-

It might also be argued that inspection of land would involve a greater invasion of privacy than inspection of documents and things. See Hughes \& Anderson, Discovery: A Competition between the Right of Privacy and the Right to Know, 23 U. FLA. L. REv. 289 (1971). There is no indication, however, that such a concern motivated the Advisory Committee.

55. See 5A MOORE, supra note 2, If 45.01 [4], [5], [7], [9], 45.07.

56. The Advisory Committee simply commented that "giv[ing] the subpoena for documents or tangible things the same scope as provided in Rule 26(b) [would promote] uniformity." Notes of Advisory Committee on 1946 and 1948 Amendments to Rules, FED. R. CIv. P. 45(d), 28 U.S.C. app., at 7810 (1970).

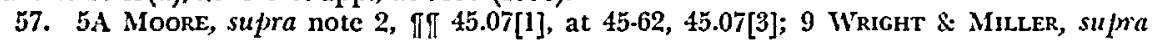
note $4, \$ 2454$, at 425 .

Rule $45(d)(1)$ was further amended in 1970 to make clear that the subpoena authorizes inspection and copying of documents and tangible things, and to protect, by a procedure analogous to Rule 34(b), the person from whom discovery is sought. Notes of Advisory Committee on 1970 Amendments to Rules, Fed. R. CIV. P. 45 (d), 28 U.S.C. app., at 7811 (1970). The "plain intention" of the 1970 amendments to Rule $45(\mathrm{~d})(1)$ was to make discovery of documents and tangible things from a nonparty under a subpoena duces tecum the same as discovery of those materials from a party under Rule 34. $5 \mathrm{~A}$ MOORE, sufra note 2, If $45.07[3]$, at $45-78$.

58. Sacks interview, supra note 18. Dean Sacks has attributed the Committec's failure to draft a discovery mechanism within the framework of the Rules to lack of time. DiscoverX Sourcebook, supra note 5, at 128. The language of Rule 34(c) itself is evidence that the Committec ran out of timc. The Rule refers to discovery actions for the production of documents and things as well as for permission to enter upon land. However, the referequce to "documents and things" is redundant, because production of documents and tangible things possessed by a nouparty can be obtained with a subpoena duces tecum under Rule 45(d). Furthermore, the Rule should have included "other property," such as structures, as well as land. See note 2 supra. Finally, the phrase "permission to enter" in Rule 34(c) is more restrictive than the drafters must have intended, because mere entry will not suffice unless complemented by ability to inspect. Since there is no plausible reason why discovery on a nonparty's land should be more limited than discovery on a party's land, "permission to enter" ought to be augmented by permission to inspect, as in Rule $34(\mathrm{a})$.

59. A provision similar to Rule 30 (b)(1) would have to be inserted in the Rules to reciuire that a party desiring to inspect a nonparty's land give notice to erery other party to the action. The first sentence of Rule $45(\mathrm{~d})(1)$ would then be amended to 
low the procedures for discovery of nonparty documents and tangible things. ${ }^{60}$

The Rules presently provide separately for requests to inspect parties' documents, tangible things and land, ${ }^{01}$ and for subpoenas to inspect nonparties' documents and tangible things. ${ }^{62}$ This organization reflects the need for different procedural devices for obtaining discovery from parties and nonparties. Following this principle, the drafters should enlarge the scope of the existing nonparty discovery device, the Rule 45(d) subpoena. The Advisory Committee adopted Rule 34 (c) only "for the present"; ${ }^{63}$ it should take up where it left off.

authorize the clerk of the court to issuc the stbpoena upon proof of-service of such notice. The second sentence of amended Rule $45(d)(1)$ might read as follows (new: matter in italics):

The subpoena may command the person to whom it is directed to produce and permit inspection and copying of designated books, papers, documents, or tangible things which constitute or contain matters within the scope of the examination permitted by Rule 26(b), and to permit entry upon designated land or other property for the purpose of inspection within the scope permitted by Rule $3 f(a)(2)$, but in that event the subpoena will be subject to the provisions of Rule 26(c) and subdivision (b) of this rule.

There would have to be minor changes in the second paragraph of Rule $45(d)(1)$ to authorize objections to and orders for inspection of land as well as inspection of "ma. terials." Furthermore, Rule 27 would have to be amended to authorize inspection of nonparty land before the filing of an action or pending an appeal from a judgment of a district court.

60. Rule $45(\mathrm{~d})$ authorizes inspection of documents and tangible things in the context of the taking of a deposition. There is no reason, however, to require a party seeking to inspect documents-or land-to depose the person from whom inspection is sought. See Wilson v. United States, 221 U.S. 361, 372 (1911); 5.1 Moore, supra note 2. $\Upsilon \uparrow 4.05[1]$. at $45-25$ to $45-26,45.07[1]$, at $45-63$ to $45-64$. But see McLcan .. Prudential Steamship) Co., 9 Fed. Rules Serv. 2d 45 b.13 (E.D. Va. 1965).

61. FED. R. Civ. P. 34.

62. FED. R. Civ. P. 45 (d).

63. Advisory Committee Note, supra note 14 . 